\title{
ВНУТРЕННЕЕ СТРОЕНИЕ ТЕКТОНИЧЕСКОЙ ЗОНЫ СЕВЕРНОГО ОБРАМЛЕНИЯ ДАХОВСКОГО КРИСТАЛЛИЧЕСКОГО МАССИВА (ЗАПАДНЫЙ КАВКАЗ)
}

\author{
В. М. Ненахов, А. В. Жабин, А. В. Никитин, С. В. Бондаренко \\ Воронежский государственный университет
}

Поступила в редакцию 7 февраля 2019 г.

\begin{abstract}
Аннотация: в статье приводятся описания фрагментов шовной зоны северного обрамления ДКМ, представляющего собой гериинский террейн внутри альпийской складчатой структуры Западного Кавказа. Дана его геодинамическая интерпретация, в соответствии с которой выделены герцинский и альпийский этапь тектонических преобразований. В герцинский этап, на коллизионной стадии взаимодействовали как минимум два континентальных блока - террейна, один из которых в альпийской структуре сохранился как ДКМ. Фрагмент второго находится в приустьевой части руч. Руфабго среди известняков раннего триаса в виде локального выступа. Коллизионные гранитоиды оказывали термальное воздействие на серпентиниты, ороговиковывая их, и при этом, в условиях сжатия сами подвергались дислокационному воздействию, в результате чего сформировалась мегабрекчия с гльбами гранитоидов. В доверхнеюрское время отражением очередного сжатия явилось формирование терригенного меланжа, матриксом которого служили аргиллиты и алевролиты авандельты. Фрагмент сутуры, сформированной в условиях коллизии и сложенной серпентинитовым меланжем, благодаря последнему, остался достаточно подвижной зоной, в которой легко реализовывались хрупко-пластические деформаџии с образованием терригенного и подновлением серпентинитового меланжа и дополнительных деформаций, наложенных на палеозойскую мегабрекчию. Кинематика разрывных дислокачий и сопровождающих явлений в процессе формирования микстита менялась несколько раз. Наиболее древние дислокации связаны со взбросо-надвигом ДКМ на сопряжённый палеозойский блок, с последующим наложением сдвиговой компоненты и объёмным течением матрикса терригенного меланжа.
\end{abstract}

Ключевые слова: Западный Кавказ, Даховский кристаллический массив, террейны, меланж, иовная зона, мегабрекчия.

\section{THE INTERNAL STRUCTURE OF THE TECTONIC ZONE OF THE NORTHERN FRAME OF DAKHOV CRYSTALLINE MASSIF (WESTERN CAUCASUS)}

\begin{abstract}
DKM. DKM is a Hercynian terrain within the Alpine folded structure of the Western Caucasus. Its geodynamic interpretation is presented. In accordance to this interpretation the Hercynian and Alpine stages of tectonic transformations are distinguished. At the Hercynian stage, at least two continental blocks (terraines) interacted at the collision stage. One of those blocks was preserved in the Alpine structure as a DCM. A fragment of the second is found in the form of a local protrusion at the mouth of the Rufabgocreek. The collisional granitoids had a thermal effect on the serpentinites, turned this rocks into hornfels, and at the same time, under the conditions of compression, they themselves were subjected to a dislocation effect, as a result of which megabreccia with granitoids were formed. In the pre-Upper Jurassic, a reflection of the next compression was the formation of terrigenous melange, the matrix of which were argillites and alevrolites of fore-delta. The suture fragment formed under the conditions of collision and folded with serpentinitemelange, remained a rather mobile zone. In this zone, brittle-plastic deformations were easily realized with the formation of terrigenous melange and the renewal of serpentinitemelange and additional deformations imposed on the Paleozoic megabreccia. The kinematics of dislocations and accompanying events was changing several times during the process of the formation of a mixtite. The most ancient dislocations are associated with upthrust of the DCM on the conjugate Paleozoic block, with the subsequent imposition of the shear component and the bulk flow of the terrigenous melange matrix.
\end{abstract}

Key words: Western Caucasus, DakhovCrystalline Massif, terranes, melange, suture zone, megabreccia. 


\section{Введение}

Западный Кавказ, как и весь Кавказский сектор Средиземноморского подвижного пояса, характеризуется крайне сложным геологическим строением, обусловленным длительной историей образования и взаимодействием разноранговых террейнов в допалеозойское и палеозойское время, в результате чего сформировалось аккреционное основание для развития мезозойских структур [1]. Одним из подобных террейнов является Даховский кристаллический массив, который с севера обрамляется сложно построенной шовной зоной, масштаб которой до настоящего времени является недооцененным. Вместе с тем её мощность, полицикличность развития, а так же меха- низм формирования могут внести существенные коррективы не только в представление о геологическом строении Западного Кавказа, но и всего кавказского региона.

\section{Геологическое строение ДКМ}

ДКМ в плане имеет форму неправильной трапеции, вытянутой на расстояние 8 км с С3 на ЮВ и с севера и юга ограниченной разрывными нарушениями. В С3 части ширина выхода 5 км, на ЮВ - до 3 км (рис. 1). Его положение в структуре Западного Кавказа наглядно демонстрируется на схематическом профиле Хамышки-Каменомосткий, составленном на основании полевых исследований авторами (рис. 2).

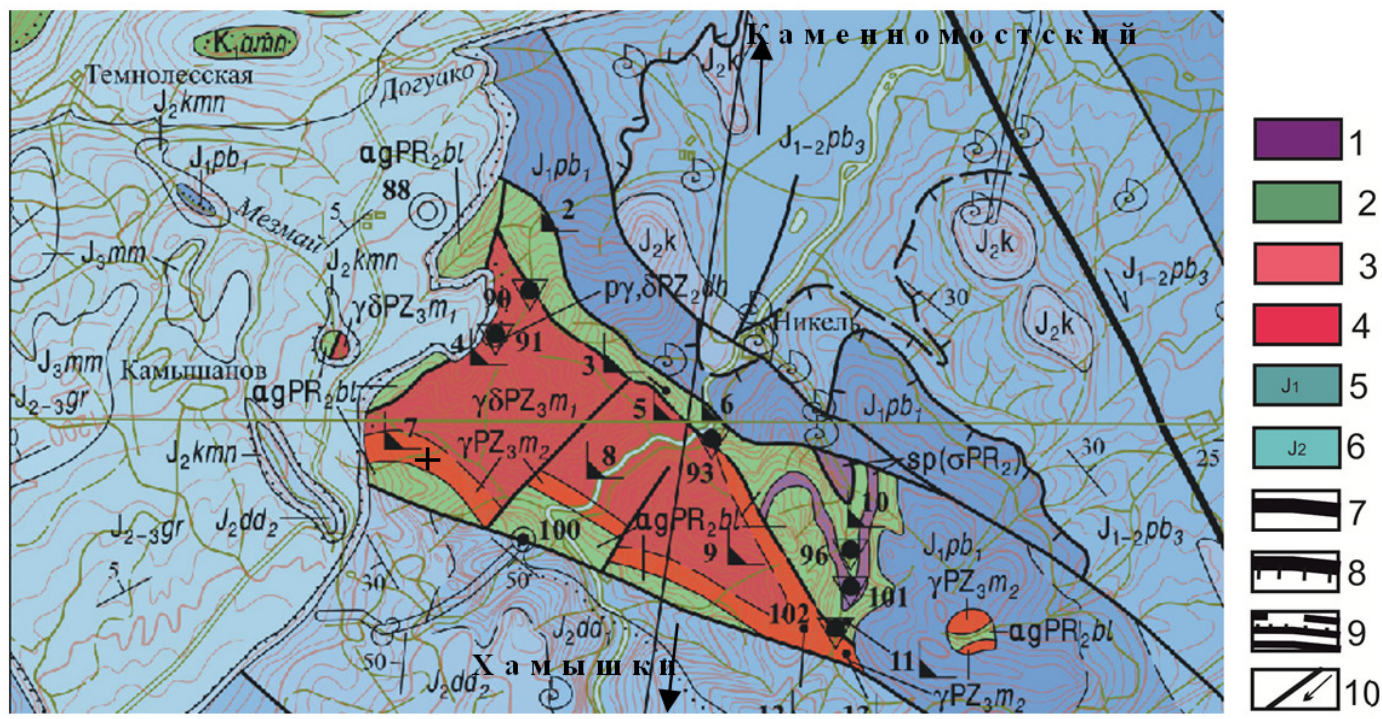

Puc. 1. Геологическая карта ДКМ [2]: 1 - серпентиниты; 2- кристаллические сланцы, амфиболиты балканского комплекса; 3-4 - малкинский комплекс: 3 - гранодиориты I фазы, 4 - лейкограниты II фазы внедрения; 5 - терригенный комплекс ранней юры; 6 - терригенные отложения средней юры; 7 - разрывные нарушения крутого падения (взбросы, сбросы, сдвиги); 8 - надвиги, 9 разнотипные стратиграфические границы; 10 - фрагмент геологического разреза по профилю Хамышки - Каменномостский.

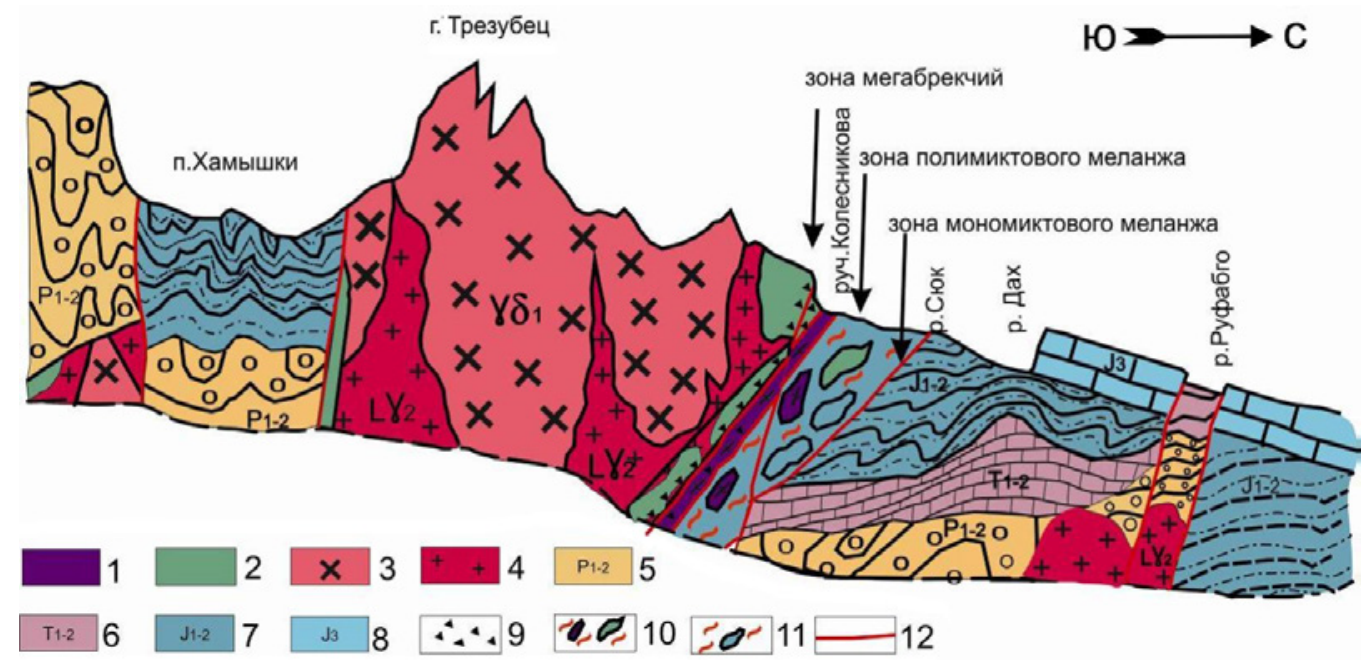

Puc. 2. Схематический геологический разрез ДКМ и его обрамления по профилю Хамышки - Каменномостский: 1 - серпентиниты; 2 - метаморфиты балканского комплекса; 3-4 малкинский комплекс: 3 - гранодиориты I фазы, 4 - лейкограниты II фазы внедрения; 5 - отложения пермской молассы, 6 - известняки триаса; 7 - терригенные отложения ранней и средней юры; 8 - карбонатные отложения поздней юры; 9-11 СВК шовной зоны: 9 - магабрекчия шовной зоны, 10 - полимиктовый серпентинитовый и терригенный меланж, 11 - мономиктовый терригенный меланж; 12 - разрывные нарушения различной кинематики. 
На юго-востоке и западе кристаллические породы ДКМ трансгрессивно перекрываются осадками нижней и средней юры, слагающими одноимённую с выступом (массивом) прямую симметричную антиклинальную складку с падением крыльев в юго-западных и северо-восточных румбах, под углами 60-70 [2]. Глубинное строение Даховского выступа практически не изучено. По данным бурения всего одной скважины (№ 88) здесь устанавливается аллохтонное залегание кристаллических пород протерозоя, которые надвинуты на терригенно-карбонатные отложения триаса. Небольшие по амплитуде надвиговые смещения северной вергентности установлены и в естественных обнажениях среди гранитоидов верхнего палеозоя, что подтверждает существование более крупных тектонических покровов. Именно крупные горизонтальные подвижки киммерийского этапа тектогенеза привели к формированию Даховского выступа, а не вертикальное перемещение, как это до сих пор считалось предыдущими исследователями.

Периферию ДКМ слагают кристаллические образования балканского метаморфического комплекса $(\mathrm{agPR} 2 \mathrm{bl})$, относимые по [2] к протерозою и составляющие 20\% пород массива. По данным [3] протолитом для них служат образования турнейского возраста (353 млн лет). Центральную часть занимает прорывающий их массив позднепалеозойских гранитоидов малкинского плутонического комплекса. Развитие последнего проходило в два этапа. Образования первой фазы внедрения сложены средне-крупнозернистыми амфибол-биотитовыми гранодиоритами, возраст которых составляет 301 млн лет [3], отвечающий границе верхнего карбона и нижней перми, что коррелируется с завершением герцинского тектогенеза.

Породы второй фазы представлены небольшими линейно вытянутыми телами, разноориентированными дайками, жилами и штоками мусковитовых и двуслюдяных гранитов, обрамляющих гранитоиды первой фазы с юго-запада и востока. Кроме того, в гранитоидах первой фазы малкинского комплекса в виде ксенолитов, размером от десятков сантиметров до 250 м в поперечнике, встречаются плагиограниты и диориты, относимые [2] к даховскому плагиогранитдиоритовому плутоническому комплексу. Таким образом, среди гранитоидов достаточно отчётливо выделяются три разновидности.

Первая - представлена плагиогранитами и кварцевыми диоритами даховского комплекса, встречающимися в виде ксенолитов в малкинских гранодиоритах первой фазы.

Плагиограниты. Серые, разгнейсованные, состоящие из кварца 21-36\%, плагиоклаза (олигоклазальбит) 40-65\%, биотита до 14\%, хлорита 2-19\%, эпидота, роговой обманки $0-12 \%$, редко вторичного мусковита до 10\%. Отмечается наложенный микроклин 0-8\%. Вторичные минералы представлены кальцитом, серицитом, соссюритом, пренитом, хлоритом. При уменьшении содержания кварца (15$20 \%$ ) породы переходят в тоналиты. По соотноше- нию $\mathrm{Na}_{2} \mathrm{O} / \mathrm{K}_{2} \mathrm{O}$ равным 1,5-6 [4] породы относятся к натриевому ряду [5].

Квариевые диориты [6] зеленовато-серые, часто гнейсовидные породы, состоят из кварца 5-15\%, плагиоклаза (олигоклаз-андезин) 45-60\%, биотита 0$30 \%$, роговой обманки 20-30\%. В них отмечается хлоритизация биотита и роговой обманки, широко развиты соссюрит, эпидот, кальцит, пренит, присутствуют рудные минералы. Местами проявлены наложенный микроклин (до 3\%) и альбитизация плагиоклазов. Из акцессорных встречаются апатит, сфен, циркон.

Вторая - гранодиориты, относящиеся к первой фазе малкинского гранитоидного комплекса $\left(\gamma \delta \mathrm{PZ}_{3} \mathrm{~m}_{1}\right)$. Минеральный состав: биотит (15-20\%), роговая обманка (10-15\%), кварц (до 25\%), калишпат (17-20\%), представленный преимущественно микроклином, плагиоклаз (до 30\%), мусковит (до 3\%). Структура средне-крупнозернистая, участками - порфиробластовая. При преобладании гранодиоритов, минеральный и петрохимический состав пород весьма разнообразен с переходами к гранитам, кварцевым диоритам и их умеренно-щелочным разностям [7, 8, 9]. Соотношение $\mathrm{Na}_{2} \mathrm{O} / \mathrm{K}_{2} \mathrm{O}<1$ (до 0,15), при этом большинство исследователей отмечают вторичный, ксеноморфный характер микроклина, его порфиробластез и широко проявленную микроклинизацию плагиоклазов, наряду с небольшим количеством первичного микроклина. Часто по контактам зёрен встречаются пертиты, червеобразные вростки кварца. Иногда отмечаются мирмекиты. Плагиоклазы часто зональные (олигоклазандезин), альбитизированные. Разновидности гранодиоритов: биотитовые, мусковит-биотитовые, биотит амфиболовые, редко мусковит содержащие.

Третья - граниты второй фазы малкинского комплекса $\left(\gamma \mathrm{PZ}_{3} \mathrm{~m}_{2}\right)$. Слагают штоки (до 1600×350 м) дайки, жилы, секущие образования даховского и гранитоиды первой фазы малкинского комплексов, а так же более древние метаморфические породы. Они сложены лейкократовыми мелкозернистыми и аплитовидными разностями. Минеральный состав: калишпат (до 35\%), плагиоклаз (до 25\%), кварц (до 35\%), мусковит (до 5\%), биотит (до 2\%). Количество их варьирует даже в пределах небольших тел. По петрохимии эти породы относятся к гранитам нормального ряда, реже к умеренно щелочным $\left(\mathrm{K}_{2} \mathrm{O}+\mathrm{Na}_{2} \mathrm{O}\right.$ до $\left.9 \%\right)$ гранитам и лейкогранитам [2].

Возрастные датировки гранитоидов малкинского комплекса, определённые K-Ar методом, колеблются в широких пределах от 172 до 321 млн лет (гранодиориты 292, граниты 172-315, аплиты 192240, аляскиты 192-284, пегматиты 230-312). Возраст гранитоидов малкинского комплекса согласно [3] принимается верхнепалеозойским.

Породы балканского метаморфического комплекca, слагающие северную и южную части ДКМ, тектонически контактируют с отложениями нижнейсредней юры. Сам контакт часто подчёркивается интенсивно меланжированными серпентинитами и их 
протрузиями. Внутреннее строение комплекса весьма сложное за счёт разрывных и складчатых дислокаций, многочисленных даек, жил пегматитов кварцевого, баритового и карбонатного метасоматоза [10-15]. В связи с этим стратификация образований комплекса весьма условна. На западе (р. Догуако, р. Белая) отмечается неравномерное чередование амфиболитов (до 8 м) и амфиболовых гнейсов (до 0,5 м) и биотит- амфиболовых гнейсов (до 6 м), иногда с прослоями мусковитовых сланцев (до 0,3 м). В бортах долины р. Белой отмечаются гранат содержащие разности.

Преобладающие амфиболиты и амфиболовые гнейсы состоят из роговой обманки 40-70\%, плагиоклазов 16-30\%, кварца 8-12\%, биотита $1-5 \%$. Из акцессорных отмечаются магнетит, титано-магнетит, сфен, лейкоксен, циркон, апатит. Вторичные минералы представлены серицитом, эпидотом, карбонатами. В амфибол-биотитовых разностях: плагиоклаз 40$55 \%$, биотит 12-20\%, кварц 10-20\%, амфибол 7-25\%, микроклин 5-15\% и др. Общая мощность более 500 м.

Разброс изотопных датировок (от 984 до $430 \mathrm{млн}$ лет по [16] и до 353 млн лет по [3]) указывают на полигенность и полихронность протолитов балканского метаморфического комплекса.

\section{Особенности внутреннего строения северного обрамления ДКМ}

Северной границей ДКМ служит тектоническая зона сложной разрывной кинематики, прослеженная вкрест её простирания от правого борта р. Сюк (правый приток р. Белая) до верховьев руч. Колесникова (левый приток р. Белая) на растоянии 3,0 км. Упомянутая структура обнаруживает признаки, характерные для шовных зон, а именно хаотическое внутреннее строение меланжевого типа [17] с многочисленными блоками разнообразных по вещественному составу и возрасту пород осадочного, метаморфического и магматического происхождения, погруженными в матрицу интенсивной тектонизации. Последняя, подчёркивается наличием флюидальных текстур, проявленных в аргиллитовом или серпентинитовом субстрате, а также появлением участков с брекчиевидной текстурой, характерной для хрупких кристаллических пород. В отдельных случаях хрупко-пластические деформации проявлены одновременно. Мощность зоны тектонизации во врезе р. Белая, где она хорошо вскрыта и обнажена, имеет видимую мощность до 1,5 км от устьевой части руч. «Родниковый» до устья р. Сюк.

С юга на север в зоне отчётливо выделяются три подзоны: первая - шириной 150-200 м сложена мегабрекчией, вторая (до 300 м) - серпентинитовым меланжем полимиктового типа, третья (более 800 м) мономиктовым терригенным меланжем (рис. 2).

Мегабрекчиевая подзона состоит из глыб яйцевидной, шарообразной сглажено-треугольной формы с размерами от десятков сантиметров до десятков метров в поперечнике. Глыбы разнообразны по составу и представлены лейкогранитами малкинского комплекса, песчаниками раннего триаса, амфиболитами, кристаллическими сланцами и метапесчаниками балканского метаморфического комплекса, а также апогарцбургитовыми серпентинитами и серпофитами.

Мегабрекчия практически безматричная (на долю матрикса приходится не более $10 \%$ от всего объёма), в то же время матрица очень хорошо выражена в виде многослойной «скорлупы» облекающей каждую глыбу (рис. $3 a)$.

«Скорлупа» плитчатая, линзовидная, с многочисленными зеркалами скольжения, характерными для меланжированного серпентинита (рис. 3б), однако, на поверхности сколов, ортогональных зеркалам скольжения, она скорее напоминает перетёртый метапесчаник.

Серпентинитовый меланж (вторая подзона) на изучаемой территории прослеживается на расстоянии более 10 км от верховья руч. Колесникова (левый борт р. Белая) до устьевой части руч. Кленовый (правый борт р. Белая), и далее до среднего течения руч. Сюк, ширина зоны до 300 м.

Свежие неизменённые материнские породы представлены апогарцбургитами интенсивно, часто полностью серпентинизированными и тектонизированными. Не измененные гарцбургиты практически не встречаются и распознаются по реликтовым структурным признакам.

Для них характерна мелко-, среднезернистая структура, массивная текстура, черная с зеленоватым оттенком окраска.

Минеральный (судя по реликтовым зёрнам) состав: оливин 50-60\%, ортопироксен 40-50\%. И оливин и пироксен практически полностью замещены петельчатым серпентином (хризотил), который в тектонизированных зонах и особенно вблизи контактов с гранитоидами замещается чешуйчатой разновидностью (антигоритом).

Ортопироксен образует идиоморфные зерна короткопризматического облика, темно-серого до черного цвета, на сколе с хорошо выраженной по сравнению с оливином спайностью. Степень преобразования оливина в серпентин намного выше, чем у пироксенов, и при этом выделяется значительное количество магнетита, за счет чего порода приобретает черный цвет.

Наложенные процессы (серпентинизация, тектонизация) проявляются в объеме всей породы и, особенно, на локальных участках. Интенсивно серпентинизированный апогарцбургит, в зонах серпентинитового меланжа, образует как матричную породу, так и основную массу включений - обдавышей. Порода, слагающая субстрат, темно-серого до черного цвета с зеленоватым оттенком, тонкозернистая, сильно тектонизирована, перемята, катаклазирована. Апогарцбургиты в составе меланжа слагают лишь реликтовые тела, объем которых от объема всего серпентинитового меланжа не более 10\%. Форма этих тел линзовидная, округлая, рулетообразная, что характерно для обдавышей меланжа. На участках метасоматического преобразования серпентиниты преобразуются в серпофиты. 
Последние светло-зелёные, массивные, с тонкими разно ориентированными прожилками. Структура петельчатая, секториальная (реликты идиоморфных кристаллов оливина). Секторы разбиты сетью равномерных прожилков тальк-карбонатного мелкоагрегатного материала. Часть прожилков до 1 мм
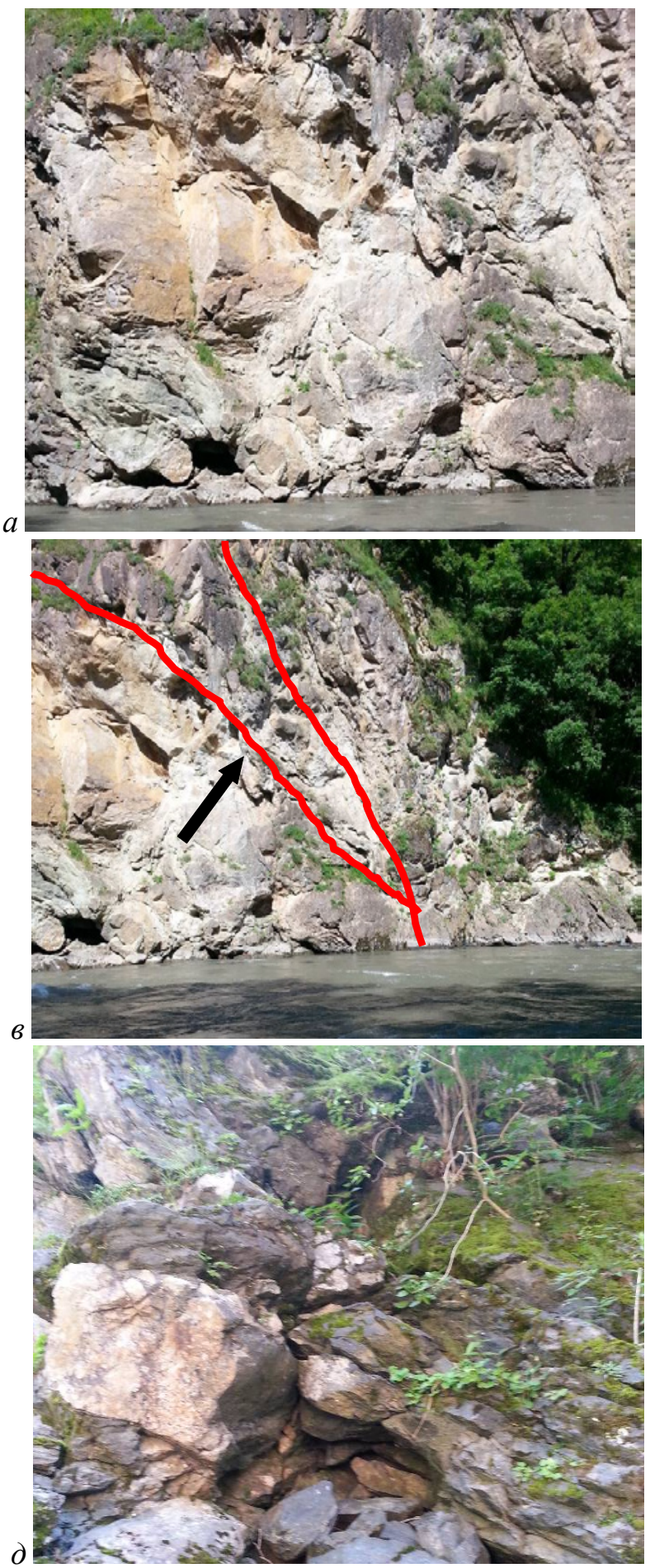

шириной чисто талькового, либо тальк-опал-тридимитового выполнения с кубическими кристаллами пирита. Такие прожилки занимают не более 5-7\% объёма всей породы. Серпофитовые жилы, при последующей тектонизации, также приобретают форму обдавышей.
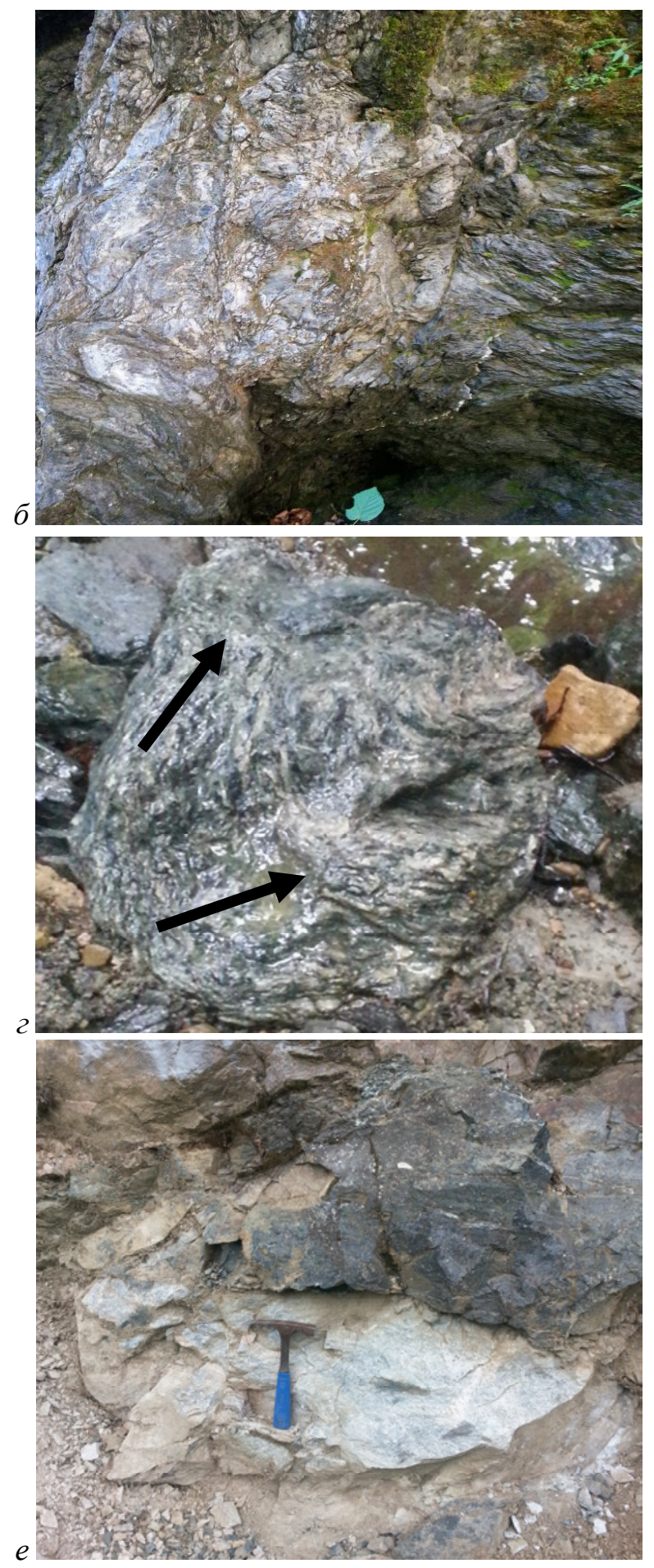

Puc. 3. $a$ - мегабрекчия (Левый борт русла р. Белой); $\sigma$ - меланжированный серпентинит; 6 - контакт мегабрекчии с серпентинитами (показан стрелкой); г - серпентинитовые обдавыши (показаны стрелкой) внутри матрицы серпентинита; $\partial-$ обдавыш лейкогранита в серпентинитовой матрице; $e$ - амфиболитизированный серпентинит на контакте с обдавышем лейкогранита. 
В зоне меланжа, наряду с серпентином, обычны интенсивно ороговикованные его разности. В них сохраняются зеркала скольжения и внешне они отличимы от серпентина только повышенной прочностью. При этом в них появляется роговиковая структура, лучистый амфибол и моноклинный пироксен, в виде прожилков широко проявлен тридимит.

Среди обломков - обдавышей встречаются разнообразные по составу роговики, в том числе кварцпироксеновые, пироксен-амфибол-полевошпатовые с типично роговиковыми полигональными структурами; иногда структуры более сложные - узловатые, вытянуто-полигональные с очень причудливыми узорчатыми взаимно проникновениями кварца и кварц-пироксенового агрегата.

Наряду с роговиками в виде обдавышей присутствуют чёрные, массивные с элементами тонкой директивности амфиболиты. Структура гранобластовая, узловатая. Узелки овальной формы, размером до $2 \times 3$ мм, сложены тонким агрегатом полевого шпата и эпидота. Амфибол зеленовато-голубой с обратной схемой абсорбции (глаукофан?), образует удлинённопризматические и волокнистые кристаллы, за счёт ориентировки которых проявляется директивность.

От мегабрекчии серпентинитовая зона отделяется субвертикальным разломом взбросового типа, наложенного на полого залегающие (первичные) элементы дислокации явно предшествующие субвертикальным перемещениям (рис. 3в).

В обнажении в устье руч. Кленовый над урезом воды р. Белая видно, что дислокации, проявленные в серпентините и относящиеся к надвиговому типу имеют пологую (под углом около $10^{\circ}$ ) ориентировку падений тектонических линз и чешуй (размером от нескольких см. до 10-15 см) в южных румбах, тогда как наложенные на них дислокации субвертикальны и резко «обрезают» субгоризонтальные. И в тех и в других наблюдаются «обдавыши» линзовидной и веретёнообразной формы, сложенные серпентинитом с массивной текстурой, облекающиеся матрицей с чешуйчатой текстурой и флюидальным рисунком (рис. 32).

«Флюидальный» серпентинит более твёрдый, обезвоженный, по макроскопическим характеристикам часто приближается к кристаллическим метапесчаникам. Линзы-чешуи в них часто зонального строения, центральная часть которых представлена раскристаллизованным бластокатаклазитом, содержащим одновременно оливин (форстерит), хлорит и кристобалит, а оболочка - серпентинитовым материалом с многочисленными зеркалами скольжения.

В серпентинитовой матрице содержатся фрагменты даек лейкогранитов как с небольшими (до 10-30 см) амплитудами перемещения друг относительно друга, так и с существенными, о чём свидетельствуют округлой формы «обдавыши» лейкогранитов вне видимой связи с дайками (рис. $3 \partial$ ).

На контакте с дайками серпентиниты ороговиковываются, и становятся более крепкими, при этом они преобразуются в амфиболито подобную породу, содержащую фрагменты тектонически переработанных лейкогранитов в виде обдавышей (рис. $3 e$ ).

Соотношение гранитоидов и серпентинитов сложное из-за неоднозначности возрастных взаимоотношений. С одной стороны дайки гранитов прорывают серпентиниты, ороговиковывая их, а с другой - сами растаскиваются при пластическом течении последних, т.е. серпентиниты, как исходные породы до гранитоидные, но их меланжирование происходило и после внедрения даек (рис. $4 a$ ).

Восточнее (руч. Сюк), между массивными, слабо тектонизированными серпентинитами и зоной серпентинитового меланжа залегают фрагменты тел (до 10 м) амфиболитов, пачки чередования амфиболитов, амфиболовых, биотит-амфиболовых, биотитовых кристаллических сланцев, среди них присутствуют кварцитовидные разности и прослои (до 0,6 м) мусковитовых сланцев.

Кристаллические сланцы часто содержат признаки метаморфической дифференциации в виде чередующихся полос лейко- и меланосом. Лейкосомы сложены кварцем и полевым шпатом (КПШ), иногда присутствует мусковит. Меланосомы обогащены биотитом и амфиболом. Структура лепидогранобластовая. Кварц с сильно проявленным эффектом волнистого погасания образует зёрна вытянутой формы с хорошо выраженной ориентировкой; его зёрна корродируют зёрна калишпата. Последний часто с хорошо выраженной микроклиновой решёткой. Микроклин пертитового строения содержит вростки альбита-олигоклаза. Биотит коричневый с сильным плеохроизмом. Амфибол представлен лучистой разностью. Встречаются разновидности сланцев, обогащённые (до 10\%) гранатом.

Помимо кристаллических сланцев, ороговикованных и не затронутых ороговикованием амфиболитов, в виде обдавышей встречаются бежевые и светлокоричневые метасоматиты, состоящие из кварца $(\sim 40 \%)$, полевого шпата (30-35\%), карбоната (до $15 \%$ ) с хлоритом (до 10\%) и эпидотом (до 10\%). Иногда карбонат в них преобладает (до 60\%) и порода по составу приближается к кальцифирам. Один из типов метасоматитов - лиственит, серая с зеленоватым оттенком порода с аллотриоморфнозернистой структурой. Состоит из кварца (тридимита $\sim 60 \%$ ), карбоната ( 30\%), мелкочешуйчатого мусковита $(\sim 10 \%)$, содержит множество прожилков тридимит - пренитового состава, а также реликтовые участки, состоящие из антигорита.

Ещё одной разновидностью пород, распространённых в виде блоков, являются песчаники буроватои светло-коричневые с пятнистым распределением окраски. Структура обломочная алевропсаммитовая, состав полимиктовый. Обломки, состоящие из кварца ( 40\%), полевых шпатов ( 30\%), слюды ( 15\%), ортопироксена (15\%), карбонатов (10\%), неокатанные, плохо сортированные, цемент кремнисто-карбонатный. Карбонат образует тонкие прожилки. 


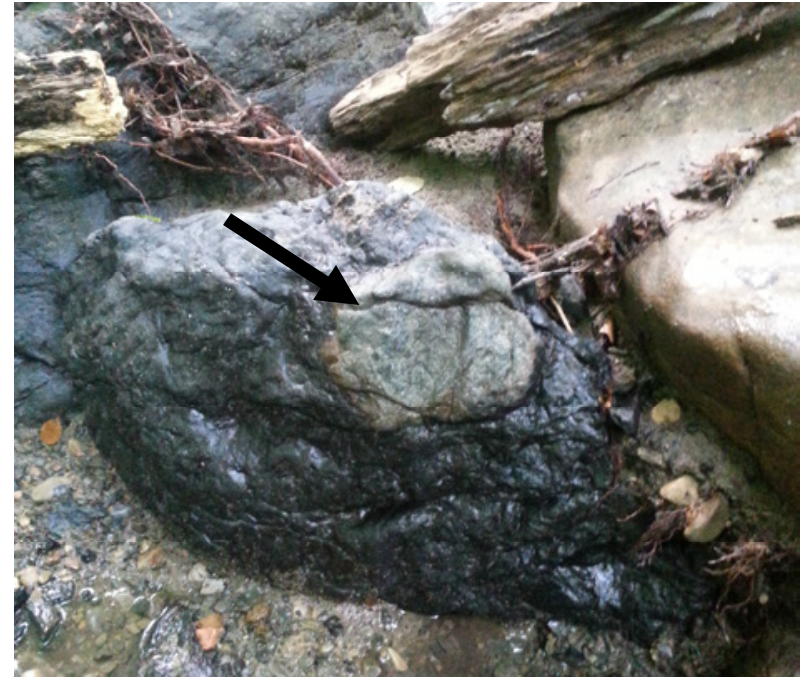

$a$
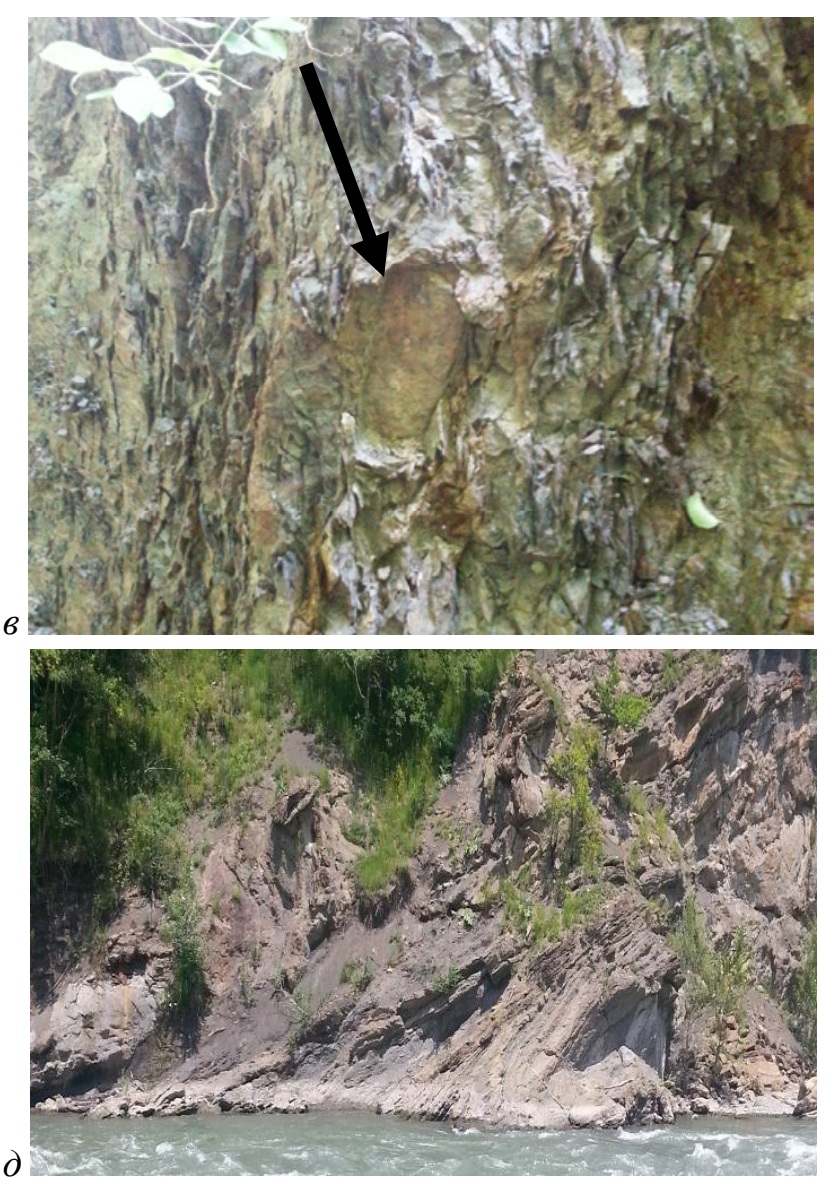

Соотношение серпентинитового меланжа (2-я зона) с терригенным меланжем (3-я зона) более простое, чем соотношение серпентинитового меланжа с мегабрекчией. Влияние термального воздействия интрузивных пород здесь не проявлено. Развиты как полимиктовый, так и мономиктовый терригенный меланж.

В бортах долины ручья Колесникова наблюдаются выходы полимиктового терригенного меланжа (рис. 4б), в котором, кроме «обдавышей» терригенных пород, встречаются тектонические блоки серпентинито-
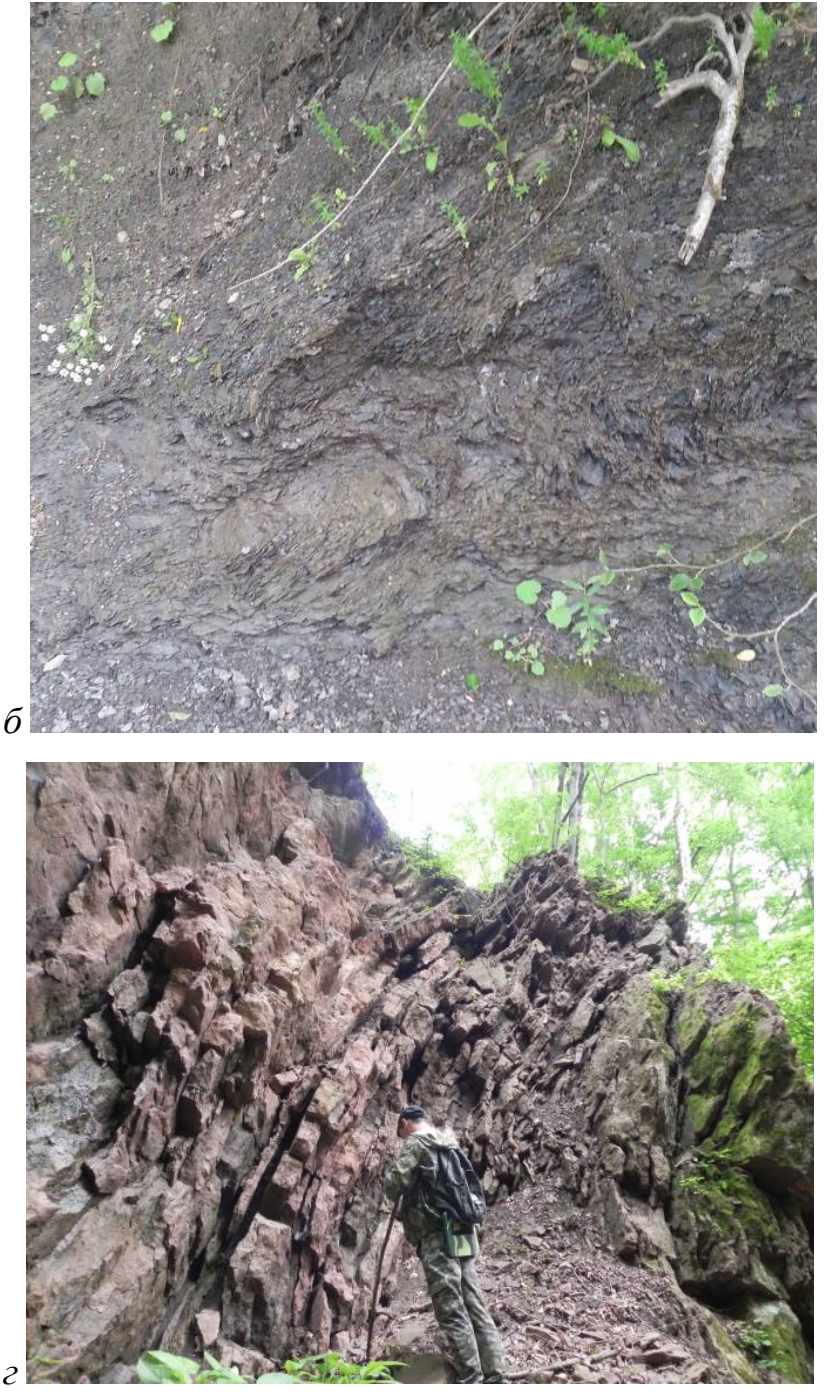

Puc. 4. $a$ - обдавыш гранита (показан стрелкой) в серпентинитовом матриксе; $\sigma$ - флюидальность в матриксе терригенного меланжа; 8 - обдавыш триасового известняка (показан стрелкой) в терригенной матрице; 2 - фрагмент складки триасовых известняков внутри поля распространения терригенного меланжа; $\partial-\phi$ рагменты складок известняков верхней юры в поле распространения терригенного меланжа.

вого состава, как слабо меланжированные, так и с предельно переработанной серпентинитовой матрицей, включающей «обдавыши» различного состава.

В 500 м от устьевой части этого ручья среди терригенного матрикса, развитого за счёт аргиллитов псебайской свиты раннеюрского возраста, встречаются блоки (рис. 48) и фрагменты складок линзовиднослоистых известняков раннего триаса.

Крупный фрагмент синклинальной складки (30×50 м) обладает субвертикальным шарниром, сви- 
детельствующим о сдвиговой компоненте в процессе формирования меланжа (рис. 42). Южное крыло складки субвертикальное, переходит в более пологое северное. Шарнир осложнён разрывным нарушением субширотного простирания. Линзовидно-слоистый облик известняков обусловлен многочисленными межпластовыми и косо-секущими подвижками.

Помимо серпентинитов и известняков триаса в подзоне терригенного меланжа, сопряжённой с подзоной серпентинитового меланжа, обычны «обдавыши», сложенные кристаллическими сланцами и амфиболитами, количество которых в северном направлении постепенно снижается. В приустьевой части р. Сюк и на левом борту р. Белая (рис. 4ठ) среди меланжированного субстрата отмечаются фрагменты сложно-деформированных известняков юрского $\left(\mathrm{J}_{3}\right)$ возраста, севернее которых аргиллиты уже не несут следов интенсивного тектонического воздействия.

Юрские отложения здесь представлены авандельтовыми фациями преимущественно терригенного состава с широко проявленными процессами подводногравитационного происхождения (зерновые потоки, складки гравитационного оползания, мусорные известняки и т.д.). Встречаются блоки гравитационного генезиса, содержащие фациальные переходы от мусорных известняков к аргиллитам. В отличие от описанных выше блоков, они погружены в аргиллит с массивной, реже слабо проявленной слоистой текстурой.

Анализ литологического и петрографического состава глыб - обдавышей, встречающихся в серпентинитовом и, в меньшей степени в терригенном матриксах, показывает их большое разнообразие, соответствуя широкому спектру Р-Т условий их образования. Среди них отмечены породы регионального (кристаллические сланцы), контактового (роговики, метасоматиты) и дислокационного метаморфизма, а также осадочные породы (песчаники, известняки триаса и юры, алевролиты и аргиллиты юры), не затронутые термальным воздействием. Сам матрикс, прежде всего серпентинитовый, преобразован в условиях широкого диапазона температур и давлений.

В 6 км южнее ДКМ наблюдаются выходы отложений пермской системы, представленные породами нижнего и верхнего отделов, которые выклиниваются с С3 на ЮВ. Нижний отдел сложен красноцветными терригенными (моласса), а верхний - сероцветными терригенно- карбонатными морскими отложениями. Северо-восточная граница с ранне-среднеюрскими образованиями проходит по субвертикальному разлому с падением сместителя на юг [2].

Здесь проявлен мономиктовый терригенный меланж. Он наблюдается на левом борту реки Белой, в 200 м от памятника Защитника Отечества, по трассе Гузерипль - Майкоп (в районе 66-го км). Терригенные породы в зоне мощностью более 50 м, интенсивно тектонизированы и превращены в терригенный меланж, состоящий из интенсивно тектонизированной аргиллитовой матрицы, в которую включены разные по размеру тектонически обработанные блоки - обдавыши. Среди них по литологическому составу доминируют тонко-зернистые песчаники и алевролиты, размер которых от нескольких сантиметров до блоков, размером $0,4 \times 1 \mathrm{M}$, реже встречаются обдавыши идентичные матричной породе. Для матричной породы характерно предельное тектоническое рассланцевание и разнонаправленный кливаж, за счет чего создается флюидальность макроструктуры.

Для обдавышей характерна веретёнообразная, линзовидная или рулетообразная форма и косая ориентировка длиной оси, относительно контакта с пермской молассой. На юго-западе пермские отложения несогласно перекрываются песчаниковой толщей позднего триаса.

С большой степенью вероятности, гранитоиды даховского массива и пермская моласса субсинхронны и относятся к орогенному этапу герцинского тектонического цикла, так как коллизионный интрузивный магматизм (в данном случае представленный малкинским комплексом гранитоидов) проявляется одновремённо с процессами горообразования. Можно предположить, что под пермской молассой распространены породы, аналогичные породам ДКМ, а, следовательно, всё поле выходов молассы следует рассматривать как верхний ярус названного кристаллического массива.

\section{Механизм формирования шовной зоны}

Тектоническая зона северного обрамления ДКМ имеет трёхчленное строение, главной составной частью которой является подзона полимиктового серпентинитового меланжа. Сложность его расшифровки заключается в том, что он представляет собой полихронный и полигенный комплекс, формировавшийся в несколько (минимум три) этапов.

Первый этап (докембрий-средний палеозой) связан с деструкцией древнего континентального блока с образованием нескольких террейнов, окружённых корой океанического типа.

Второй этап - формирование композитного континента в результате герцинской коллизии (скучивание террейнов). Коллизионная структура, сформированная на этом этапе, отвечает понятию «аккреционная система», которая предполагает формирование нескольких, иногда многочисленных офиолитовых швов.

Скучивание сопровождалось внедрением орогенных гранитоидов малкинского комплекса в гетерогенную раму, в том числе в серпентиниты, с глубокими преобразованиями последних в зонах контакта, включающими метасоматоз и ороговикование. В условиях высоких температур серпентинит, теряя воду, длительное время сохранял свои пластические свойства, что приводило к отрыву тел-сателлитов гранитоидного состава и вовлечение их в процесс меланжирования в качестве глыб-обдавышей. Подтверждением этому служит широкий спектр термально изменённых серпентинитов - от массивных и плойчатых хризотиловых и антигоритовых до ороговикованных, часто амфиболитоподобных плойчатых пород, 
содержащих глыбы-обдавыши гранитов, а также наличие разнообразных метасоматитов, в том числе лиственитов.

Меланжирование матрикса серпентинитов происходило в три стадии. Первая - это пластическая тектонизация серпентинита в относительно холодном состоянии, когда в догерцинское время в качестве обдавышей в матрикс меланжа вовлекались породы балканского метаморфического комплекса. На второй стадии происходило меланжирование в пластическом разогретом состоянии под влиянием внедрения гранитоидов в герцинскую кульминацию. Третья стадия связана с хрупко-пластическими деформациями альпийской фазы складчатости.

Третий этап - формирование мегабрекчии на финальной стадии герцинского тектогенеза и её «подновление» в альпийское время. Терригенный меланж полностью отражает альпийский тектогенез.

\section{Заключение}

Анализ всего фактического материала позволяет говорить о тектонической зоне северного обрамления ДКМ как о полигенном и полихронном типе микстита сложного генезиса (меланж в меланже), а возможно и об олистостроме в меланже, хотя однозначных признаков последнего пока выявить не удалось. К ним достаточно условно можно отнести блоки-глыбы триасовых известняков, песчаников и сопряжённого с ними терригена. Их первично олистостромовую природу можно определить по фрагментам матрикса с признаками осадочного генезиса, что в зоне высокой степени тектонизации терригенного меланжа представляется маловероятным.

В формировании микстита сложного генезиса p. Белая можно выделить три этапа - догерцинский, герцинский и альпийский. О первом из перечисленных можно говорить только предположительно, хотя он в значительной степени определил гетерогенность доальпийского основания всего Кавказа [18]. В герцинский этап, на коллизионной стадии в рассматриваемом секторе Западного Кавказа, взаимодействовали как минимум два континентальных блока - террейна. Один из них в альпийской структуре сохранился как ДКМ, а второй, фрагмент которого мы находим в приустьевой части ручья Руфабго среди известняков раннего триаса, наблюдается в виде локального выступа. Всей своей южной значительной частью он погребён под альпийской структурой. О том, что до позднепалеозойской коллизии это были самостоятельные террейны, свидетельствует наличие серпентинитов в северном обрамлении ДКМ, которые являются реликтами океанской структуры Палеотетиса. Коллизионные гранитоиды (малкинский комплекс) оказывали термальное воздействие на серпентиниты, ороговиковывая их, и при этом, в условиях сжатия сами подвергались дислокационному воздействию, в результате чего сформировалась мегабрекчия с глыбами гранитоидов.
В раннемезозойское время спаявшийся континент представлял собой область размыва и денудации, часть его была покрыта мелководным морем с терригенным и карбонатным осадконакоплением шельфового типа, о чём свидетельствуют соответствующие триасовые отложения.

В ранней и средней юре дифференциация дна бассейна увеличилась, снос терригенного материала усилился и преобладающим осадконакоплением стал терриген-авандельтовый тип.

В доверхнеюрское время отражением очередного сжатия явилось формирование терригенного меланжа, матриксом которого служили аргиллиты и алевролиты авандельты. Фрагмент сутуры сформированной в условиях коллизии и сложенной серпентинитовым меланжем, благодаря последнему, остался достаточно подвижной зоной, в которой легко реализовывались хрупко-пластические деформации с образованием терригенного и подновлением серпентинитового меланжа и дополнительных деформаций, наложенных на палеозойскую мегабрекчию.

На раннеальпийском (киммерийском) этапе в зону меланжирования дополнительно вовлекались глыбы раннетриасовых песчаников, известняков и реже карбонатных пород ранней и средней юры.

Позднеюрские массивные известняки «запечатали» эту структуру и в процессе меланжирования уже не участвовали.

Кинематика разрывных дислокаций и сопровождающих явлений в процессе формирования микстита менялась несколько раз. Наиболее древние дислокации связаны со взбросо-надвигом ДКМ на палеозойский блок, о чём свидетельствуют реликтовые структуры с пологим падением в южных румбах.

В более позднее время напряжения неоднократно менялись. Так, на фоне достаточно хорошо проявленной сдвиговой компоненты (вертикальные шарниры складчатых структур в терригенном матриксе, с тектоническими блоками - «обдавышами» с вертикальной ориентировкой длинных осей) встречаются зоны с шаровидными «обдавышами» - свидетелями многократного изменения вектора напряжений. Об этом же свидетельствует и разно ориентированная флюидальность в матриксе терригенного меланжа за счёт объёмного разнонаправленного пластического течения.

\section{ЛИТЕРАТУРА}

1. Гамкрелидзе, И. П. Докембрийско-палеозойский региональный метаморфизм, гранитоидный магматизм и геодинамики Кавказа / И. П. Гамкрелидзе, Д. М. Шенгелия. - М.: Научный мир. 2005. - 460 с.

2. Объяснительная записка к государственной геологической карте Российской федерации масштаба 1:200000. Серия кавказская. Лист L-37-XXXV (Майкоп) / Под редакцией К.О. Ростовцева. Санкт-Петербург: 2004. - 240 с.

3. Палеозойский возраст высокобарических метаморфических пород даховского выступа (северо-западный Кавказ): результаты U-Pb геохронологических исследований / М.Л. Сомин [и др.] // Докл. РАН. - Т. - 416. - № 3.- 2007. - С. $360-363$. 
4. Ломизе, М. Г. Фациальная изменчивость келловейских отложений бассейнов рек Белой и Пшехи (Северный Кавказ) в связи со структурно-фациальной зональностью этой территории / М. Г. Ломизе // Бюллетень Московского общества испытателей природы. Отдел геологический. - 1961. T. - 36. - № 1. - С. 89-98.

5. Афанасьев, Г. Д. Формации изверженных пород Северного Кавказа по данным абсолютного возраста / Г. Д. Афанасьев // Геология CCCP, T.IX, ч. 1, 1968. -473 с.

6. Войткевич, Г. В. О корреляции докембрийских формаций юга Русской платформы и Северного Кавказа / Г. В. Войткевич, Г. И. Лебедько // Тезисы докладов IV конференции по геологии и полезным ископаемым Северного Кавказа. Ессентуки, 1974. - С. 63-64.

7. О геологической интерпретации радиологических данных по определению абсолютного возраста горных пород / Г. Д. Афанасьев [и др.] // Изв. АН СССР, сер. геол. - № 1. - 1962. - C. $26-40$.

8. Геология магматических комплексов Северного Кавказа и основные черты, связанной с ними минерализации. / Г. Д. Афанасьев. - Тр. ИГЕМ, вып. 20, изд. АН СССР, 1958. - 139 с.

9. Петрология метаморфических комплексов Большого Кавказа / Д. М. Шенгелиа [и др.]. - АН СССР. - М., Наука, 1991. -232 c.

10. Геологические формации Западного Предкавказья / А.Г. Алексин [и др.] - М., Наука, 1973. - 156 с.

11. Геология СССР. Т. IX, (Северный Кавказ) ч.1, Геологическое описание. - М.,1968. - 759 с.

12. Закруткин, В. В. Сахрайско-Белореченский кристал- лический массив - крайнее западное окончание полосы выходов фундаментов Кавказа / В. В. Закруткин, Ю. В. Попов, В. В. Иванов // В кн: Проблемы геологии, полезных ископаемых и экологии юга России и Кавказа. Материалы II международной конференции. Новочеркасск. Т. 1. 1999. C. 36-40.

13. Закруткин, В. В. Формационный анализ как метод стратиграфических корреляций древних метаморфических комплексов Кавказа. / В. В. Закруткин, Ю. В. Попов, В. В. Иванов // В кн: Геология и минерально-сырьевая база Северного Кавказа. Материалы IX международной научно- практической геологической конференции. Ессентуки, 2000. - С. 56-67.

14. Заридзе, Г. М. Петрология метаморфических образований северного склона Большого Кавказа (Балкария, Карачай, Адыгея) / Г. М. Заридзе, Н. Ф. Татришвили - Тр. Геол. ин-та АН Грузинской ССР, Тбилиси, 1974. - 200 с.

15. Объяснительная записка к стратиграфической схеме юрских отложений Северного Кавказа (под ред. Безносова М.С.). - М., Недра.- 1973. - 194 с.

16. Чачикий, В. П. Некоторые петрологические особенности древних кристаллических пород Западного Предкавказья и С-3 Кавказа. / В. П. Чаицкий // Труды КФ ВНИИ, вып. 17. Л. Недра, 1966. - С. 368-365.

17. Ненахов, В. М. Геологическое картирование хаотических комплексов. / В. М Ненахов, В. Ю. Лыточкин, А. С. Перфильев. -М., Геокарт, 1992. - 230 с.

18. Большой Кавказ в альпийскую эпоху / Л. И. Дёмина [и др.]. - М.: ГЕОС. 2007. - 368 с.
ФГБОУ ВО «Воронежский государственный университет»

Ненахов Виктор Миронович, доктор геологоминералогических наук, профессор, заведующий кафедрой общей геологии и геодинамики

E-mail:nenakhov@geol.vsu.ru

Тел.: +7 (473) 2208989

Жабин Александр Васильевич, доцент кафедры общчей геологии и геодинамики, кандидат геолого-минералогических наук

E-mail:Zhabin@geol.vsu.ru

Тел.: +7 (473) 2208588

Никитин Александр Васильевич, кандидат геолого-минералогических наук, доиент кафедры общей геологии и геодинамики

E-mail: nikav1960@mail.ru

Тел.: +7 (473) 2208588

Бондаренко Светлана Владимировна, доцент кафедры обией геологии и геодинамики, кандидат геологоминералогических наук E-mail: swbondarenko@hotmail.com Тел.: +7 (473) 2208926

\section{Voronezh State University}

Nenakhov V. M., Doctor of the Geological and Mineralogical Sciences, Professor, Head of the General Geology and Geodynamics Department

E-mail:nenakhov@geol.vsu.ru

Tel.: +7 (473) 2208989

Zhabin A. V., Candidate of Geological and Mineralogical Sciences, Associate Professor of the General Geology and Geodynamics Department

E-mail:Zhabin@geol.vsu.ru

Tel.: +7 (473) 2208588

Nikitin A. V., Candidate of Geological and Mineralogical Sciences, Associate Professor of the General Geology and Geodynamics Department

E-mail:nikav1960@mail.ru

Tel.: +7 (473) 2208588

Bondarenko S. V., lecturer of General Geology and Geodynamics Department, Candidate of Geological and Mineralogical

Sciences

E-mail: swbondarenko@hotmail.com

Tel.: +7 (473) 2208926 